\title{
PEMBERDAYAAN WAKAF UANG SEBAGAI UPAYA PENINGKATAN KESEJAHTERAAN MASYARAKAT
}

\author{
Moh. Ah. Subhan ZA \\ Universitas Islam Lamongan \\ e-mail: subhanza@ymail.com
}

\begin{abstract}
Waqf is a form of worship that has a high sense of solidarity towards human beings. Its existence has greatly helped the development of proselytizing in Islamic countries. But, in the implementation of the waqf is limited only in the construction of worship and education places. This is because the understanding of most people who say that waqf can only be done with immovable property such as land. Whereas on the other hand, there are other ways of waqf that has far more great benefit than immovable object, that is waqf of money. The waqf of money is a strategic step to improve the welfare of the community by investing in Islamic financial institutions with the principle of profit sharing (mudharabah and musyarakah), rent (Ijarah), murabahah or by opening a business. The results of the management of money waqf are then used for social purposes such as to improve Islamic education, Islamic hospital construction, assistance of economic empowerment of the community as well as the aid of religious facilities and infrastructure. After understanding the great potential of the money waqf, it is necessary for us to do. First, we must change the understanding of the waqf conception that has been believed by the Indonesia community up till now that waqf is limited to the immovable endowments. Second, the socialization on existence of waqf money along with its concept to society is has to be done. Third, the certificate of money waqf should not be with a large nominal value. There should be at least a fraction of 20,000, 10,000 or even 5,000, so that community participating in this money of waqf becomes more. Fourth, the benefits of productive endeavor of the waqf fund should be immediately channeled to the eligible community as it relates to the belief of waqif and so that the community knows about the benefits of the money waqf soon. Fifth, the disbursement of profit to the poor should not only be money, but also a business that can elevate their economy. Sixth, management of money waqf should not only be in sharia financial institutions, but also in the community such as mosques, madrasah or nongovernmental organizations. In this way, it will facilitate the scope of the community and can increase the amount of community participation in waqf.
\end{abstract}

Keywords: money waqf, cash waqf, community prosperity

\section{Pendahuluan}

Wakaf merupakan ibadah yang mengalirkan pahala secara terus menerus untuk orang yang berwakaf meskipun orang yang bersangkutan sudah meninggal. Hal ini sebagaimana dinyatakan dalam sebuah hadis riwayat Imam Muslim, sebagai berikut:

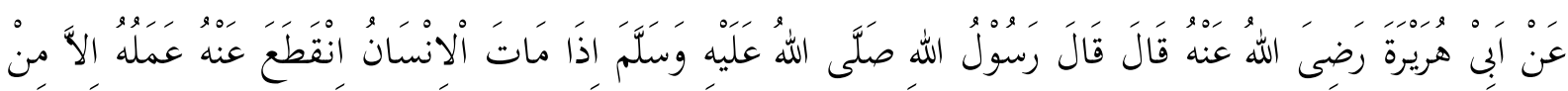




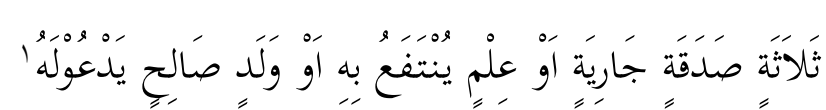

"Diriwayatkan dari Abu Hurairah, dia berkata bahwa Rasulullah bersabda: apabila manusia meninggal dunia, maka terputuslah pahala perbuatannya kecuali tiga perkara: sadaqah jariyah, ilmu yang diambil manfaatnya atau anak saleh yang berdoa untuknya".

Pernyataan "sł̧daqah jaðৈyah" dalam hadis di atas oleh sebagian ulama diartikan dengan wakaf. $^{2}$ Wakaf merupakan bentuk amalan ibadah yang mempunyai rasa solidaritas tinggi terhadap sesama manusia. Keberadaannya telah banyak membantu pengembangan dakwah islamiyah di negara-negara Islam, baik untuk pembangunan tempat-tempat ibadah atau pembangunan tempat pendidikan. ${ }^{3}$ Akan tetapi yang perlu kita kembangkan adalah bagaimana wakaf yang ada selama ini tidak hanya digunakan untuk pembangunan tempat-tempat ibadah dan pendidikan saja, tetapi juga dapat dimanfaatkan bagi pengembangan usaha produktif yang hasilnya digunakan untuk kesejahteraan ummat. ${ }^{4}$

Salah satu langkah strategis agar wakaf bisa digunakan untuk pengembangan usaha produktif adalah dengan mengoptimalkan wakaf dalam bentuk benda bergerak seperti uang. Dengan uang tersebut bisa digunakan untuk usaha-usaha yang hasilnya digunakan untuk kepentingan kesejahteraan umat. Hal ini dipandang sangat penting sejalan dengan dinamika dan perubahan dalam masyarakat apalagi sejak terjadinya multi dimensi dalam kehidupan bangsa kita yang dipicu oleh krisis ekonomi sejak 1998.

Dewasa ini, Pelaksanaan wakaf uang banyak dilakukan di lembaga-lembaga keuangan syariah, akan tetapi dalam pelaksanaannya belum berjalan secara maksimal, hambatan tersebut dikarenakan beberapa faktor, di antaranya masih banyaknya masyarakat muslim yang masih beranggapan wakaf hanya bisa dilaksanakan dengan benda tidak bergerak dan juga masih belum optimalnya manajemen wakaf di lembaga keuangan tersebut. Oleh karena itu, tulisan ini diharapkan menjadi penggugah kesadaran bagi masyarakat dan pelaksana wakaf di lembaga-lembaga perwakafan.

\section{Pengertian Wakaf}

Secara bahasa wakaf berasal dari kata waqafa sinonim dari kata hłbasa yang berarti berhenti, diam di tempat atau menahan. Kata waqafa merupakan bentuk masłlar dari ungkapan yang memberikan arti menahan sesuatu di jalan Allah: ${ }^{5}$

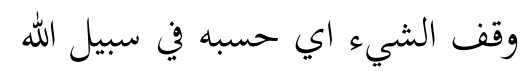

Sedangkan para ulama berbeda pendapat tentang arti wakaf secara istilah (hukum). Mereka mendefinisikan wakaf secara beragam, sesuai dengan perbedaan mazhab yang mereka

\footnotetext{
${ }^{1}$ Muslim, Słh halal-Muslim, jilid 2 (Jakarta: Daæal- Ihła >al-Kutub al-'Arabiyyah, t.th.), 14.

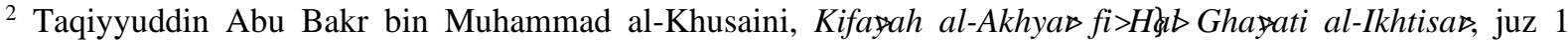
(Surabya: al-Hidayah, t.th), 319 .

${ }^{3}$ Direktorat Pemberdayaan Wakaf - Dirjen Bimbingan Masyarakat Islam, Strategi Pengembangan Wakaf Tunai di Indonesia (Jakarta: t.p. 2006), 74.

${ }^{4}$ Muhammad Abid Abdullah al-Kabisi, Hukum Wakaf (Jakarta: Dompet Dhuafa Republika dan Ilman, 2004), 7.

${ }^{5}$ Ahmad Warson Munawir, Kamus Arab Indonesia Munawair (Surabaya: Pustaka Progresif, 1997), 1683.
} 
anut, baik dari segi syarat pendekatan dalam masalah wakaf maupun pemilik harta wakaf setelah diwakafkan. Berikut adalah pengertian wakaf menurut para fuqaha $>6$

1. Menurut Mazhab Syafi'iyah

Mazhab ini mengartikan wakaf dengan menahan harta yang dapat diambil manfaatnya disertai dengan kekekalan benda, dan harta itu lepas dari penguasaan wałif, serta dimanfaatkan pada suatu yang diperbolehkan oleh agama. ${ }^{7}$

a. Wakaf menurut Imam Nawawi adalah menahan harta yang dapat diambil manfaatnya tetapi bukan untuk dirinya, sementara benda itu tetap ada padanya dan digunakan manfaatnya untuk kebaikan dan mendekatkan diri kepada Allah.

b. Wakaf menurut Ibnu Hajar al-Haitami dan Syaikh Umairah adalah menahan harta yang bisa dimanfaatkan dengan menjaga keutuhan harta tersebut, dengan memutuskan kepemilikan barang tersebut dari pemiliknya untuk hal yang dibolehkan. ${ }^{8}$

2. Menurut Mazhab Hanafiyah

Mazhab ini mendefinisikan wakaf dengan menahan benda dengan memberikan legalitas hukum milik orang yang berwakaf dan yang disedekahkan adalah manfaatnya untuk kebaikan. ${ }^{9}$

a. Wakaf menurut Imam Syarkhasi adalah menahan harta dari jangkauan kepemilikan orang lain.

b. Wakaf menurut al-Mughni adalah menahan harta di bawah tangan pemiliknya disertai pemberian manfaat sebagai sedekah. ${ }^{10}$

3. Menurut Mazhab Malikiyah

Mazhab ini mendefinisikan wakaf dengan menjadikan manfaat benda yang dimiliki, baik berupa sewa atau hasilnya untuk diserahkan kepada yang berhak dengan penyerahan berjangka waktu sesuai dengan kehendak waæif. ${ }^{11}$ Wakaf menurut Ibnu Arafah adalah memberikan manfaat sesuatu, pada batas waktu keberadaannya, bersamaan tetapnya wakaf dalam kepemilikan si pemiliknya meski hanya perkiraan. ${ }^{12}$

4. Menurut Mazhab Hanabilah

Sedangkan mazhab Hanabilah mendefinisikan wakaf dengan menahan secara mutlak kebebasan pemilik harta dalam membelanjakan hartanya yang bermanfaat disertai dengan kekekalan benda serta memutus semua hak wewenang atas benda itu, sedangkan manfaatnya dipergunakan dalam hal kebajikan untuk mendekatkan diri kepada Allah. ${ }^{13}$

Sementara itu, dalam Pasal 1 Undang-Undang Nomor 41 tahun 2004 tentang Wakaf dirumuskan bahwa wakaf adalah perbuatan hukum wałif untuk memisahkan dan atau menyerahkan sebagian harta benda miliknya untuk dimanfaatkan selamanya atau jangka

\footnotetext{
${ }^{6}$ Muhammad Abid Abdullah al-Kabisi, Hukum Wakaf, 38.

${ }^{7}$ Faisal Haq, Hukum Perwakafan di Indonesia (Pasuruan: PT Garoeda Buana Indah, 1993), 3.

${ }^{8}$ Mardani, Hukum Ekonomi Syariah di Indonesia (Bandung: PT Refika Aditama, 2011), 63.

${ }^{9}$ Abu Azam al Hadi, Hukum Perwakafan Dalam Islam dan di Indonesia (Jember: Pena Salsabila, t.th.), 12.

${ }^{10}$ Mardani, Hukum Ekonomi, 63-64.

${ }^{11}$ Faisal Haq, Hukum Perwakafan, 2.

${ }_{12}$ Mardani, Hukum Ekonomi, 64.

${ }^{13}$ Abu Azam al Hadi, Hukum Perwakafan, 16.
} 
waktu tertentu sesuai dengan kepentingannya guna keperluan ibadah dan atau kesejahteraan umum menurut syariat. ${ }^{14}$

Sedangkan menurut Kompilasi Hukum Islam (KHI) adalah perbuatan hukum seseorang atau kelompok orang atau badan hukum yang memisahkan sebagian dari benda miliknya dan melembagakannya untuk selama-lamanya guda kepentingan ibadah atau kepentingan umum lainnya sesuai dengan ajaran Islam.

Dari paparan tersebut di atas, dapat diambil kesimpulan bahwa: ${ }^{15}$

1. Harta wakaf lepas atau putus dari hak milik wałif, kecuali pendapat Hanafiyah, Malikiyah, dan menurut hukum positif.

2. Harta wakaf harus kekal, kecuali pendapat Malikiyah yang mengatakan bahwa boleh mewakafkan sesuatu walaupun akan habis dengan sekali pakai, seperti makanan, asalkan manfaatnya berlanjut.

3. Yang disedekahkan hanyalah manfaatnya saja.

\section{Pengertian Wakaf Tunai}

Pada zaman dahulu wakaf banyak dilakukan dalam wujud aktiva tetap, seperti tanah dan bangunan. Namun dalam perkembangannya terdapat implementasi wakaf dengan cara "tunai" sebagaimana yang dilakukan pada masa kekhalifahan Usmaniyah. Wakaf dengan sistem "tunai" membuka peluang yang unik bagi penciptaan investasi bidang keagamaan, pendidikan, serta pelayanan sosial. Penghasilan masyarakat dimanfaatkan melalui penukaran sertifikat wakaf tunai, selanjutnya pendapatan yang diperoleh dari pengelolaan wakaf tunai tersebut dapat digunakan untuk berbagai kepentingan kemaslahatan umat. ${ }^{16}$

Wakaf uang atau tunai pada saat ini banyak dilakukan oleh lembaga keuangan syariah (LKS) sebagai penerima wakaf uang. Dana wakaf berupa uang dapat diinvestasikan pada asetaset finansial dan pada aset riil. Investasi pada aset dilakukan di pasar modal, misalnya berupa saham, obligasi, warrant, dan opsi. Sedangkan investasi pada aset riil dapat berbentuk antara lain pembelian aset produktif, pendirian pabrik, pembukaan pertambangan dan perkebunan. ${ }^{17}$

Dari pengertian tersebut dapat dirumuskan bahwa wakaf tunai merupakan dana atau uang yang dihimpun oleh institusi pengelola wakaf ( $n a z h \gg$ ) melalui penerbitan sertifikat wakaf tunai yang dibeli oleh masyarakat. Dalam pengertian lain, wakaf tunai juga dapat diartikan mewakafkan benda berupa uang atau surat berharga yang dikelola oleh lembaga perwakafan atau lembaga keuangan syariah yang keuntungannya akan disedekahkan tetapi modalnya tidak bisa dikurangi untuk sedekahnya, sedangkan dana wakaf yang terkumpul selanjutnya dapat digulirkan dan diinvestasikan oleh $n a z$; $\gg$ ke dalam berbagai sektor usaha yang halal dan produktif, sehingga keuntungannya dapat dimanfaatkan untuk kesejahteraan masyarakat secara keseluruhan. ${ }^{18}$

Wakaf uang merupakan terjemahan langsung dari istilah cash waqf yang populer di Bangladesh, cash waqf juga dimaknai sebagai wakaf tunai. Wakaf tunai dalam Departemen

\footnotetext{
${ }^{14}$ Rozalinda, Ekonomi Islam Teori dan Aplikasinya pada Aktivitas Ekonomi (Jakarta: Rajawali Press, 2014), 224-225.

${ }^{15}$ Faisal Haq, Hukum Perwakafan, 4.

${ }^{16}$ Ibid., 85-86.

${ }^{17}$ Andri Soemitra, Bank dan Lembaga Keuangan Syariah (Jakarta: Kencana, 2016), 461.

${ }^{18}$ Faisal Haq, Hukum Perwakafan, 86.
} 
Agama adalah wakaf yang dilakukan seseorang, kelompok orang, dan lembaga atau badan hukum dalam bentuk uang. ${ }^{19}$ Dalam pengertian lain, wakaf tunai atau wakaf uang dapat diartikan sebagai penyerahan hak milik berupa uang tunai kepada seseorang, kelompok orang, atau lembaga naz $\gg$ untuk dikelola secara produktif dengan tidak mengurangi atau menghilangkan aset sehingga dapat diambil hasil atau manfaatnya oleh mawqus'alayh sesuai dengan permintaan waæif yang sejalan dengan syariat Islam. ${ }^{20}$

\section{Dasar Hukum Wakaf Tunai}

Melihat popularitas wakaf uang yang belum dikenal pada masa awal Islam, maka tidak heran jika pembahasan dasar hukum wakaf uang juga sulit ditemukan dalam kitab-kitab klasik. Bahkan, wakaf pun hanya terbatas pada harta tidak bergerak sebagaimana dipahami dalam fikih klasik. Namun, seiring dengan perkembangan zaman, wakaf uang pun mendapat legistimasi hukum. Setidaknya, berikut ini dipaparkan sumber pijakan dibolehkannya wakaf uang. Sumber-sumber tersebut terdiri dari ayat al-Quran, hadis, dan pendapat ulama. ${ }^{21}$

1. Al-Quran

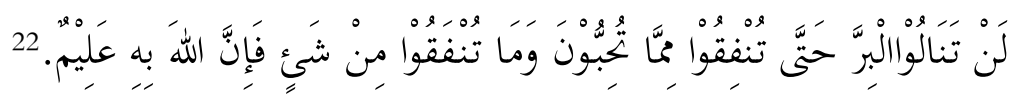

"Kamu sekali-kali tidak sampai kepada kebaktian (yang sempurna) sebelum kamu menafkahkan sebagian harta yang kamu cintai". ${ }^{23}$

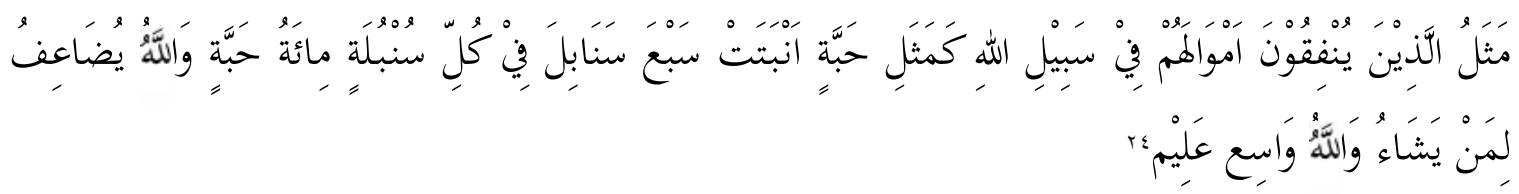

"Perumpamaan (nafkah yang dikeluarkan oleh) orang-orang yang menafkahkan hartanya di jalan Allah adalah serupa dengan sebutir benih yang menumbuhkan tujuh bulir, pada tiap-tiap bulir seratus biji. Allah melipat gandakan (ganjaran) bagi siapa yang dia kehendaki. Dan Allah Maha luas (karunia-Nya) lagi Maha mengetahui”. ${ }^{25}$

Kedua ayat di atas termasuk ayat-ayat global yang mendorong umat Islam agar menyisihkan sebagian rizkinya untuk berinfaq dan bersedekah. Wakaf termasuk bagian dari rangkaian sedekah yang justru sifatnya kekal. Dengan begitu, penggunaan kedua ayat sebagai dasar pijakan umum dibolehkannya wakaf uang menemui relevansinya. ${ }^{26}$

2. Hadis

\footnotetext{
${ }^{19}$ Sudirman Hasan, Wakaf Uang Perspektif Fiqih, Hukum Positif dan Manajemen (Malang: UIN-Maliki Press, 2011), 20-21.

${ }^{20}$ M. Nur Rianto al Arif, Lembaga Keuangan Syariah (Bandung: CV. Pustaka Setia 2012), 416.

${ }^{21}$ Sudirman Hasan, Wakaf Uang Perspektif Fiqih, 24-25.

22 al-Quran, 3: 92.

${ }^{23}$ Departemen Agama RI, Al-Quran dan Terjemah (Surabaya: CV. Fajar Mulya, 2009), 91.

24 al-Quran, 2: 261.

${ }^{25}$ Departemen Agama RI, Al-Quran dan Terjemah, 65.

${ }^{26}$ Sudirman Hasan, Wakaf Uang Perspektif Fiqih, 25-26.
} 


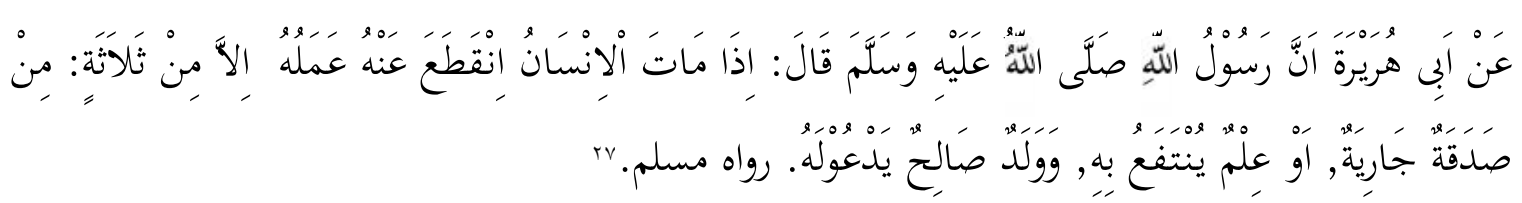

"Dari Abu Hurairah, sesungguhnya Rasulullah SAW bersabda: apabila manusia wafat, terputuslah amal perbuatannya, kecuali dari tiga hal, yaitu sedekah jariyah, ilmu yang bermanfaat dan anak sholeh yang mendoakannya". ${ }^{28}$

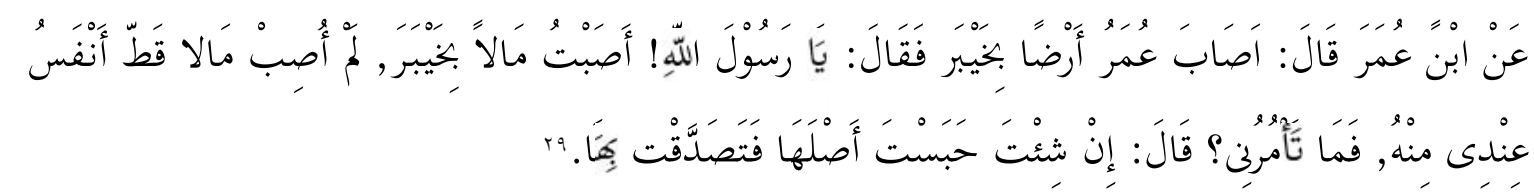

"Diriwayatkan dari Ibnu Umar r.a. bahwa Umar bin al-Khattab r.a. memperoleh tanah (kebun) di Khaibar, lalu ia datang kepada Nabi SAW untuk meminta petunjuk mengenai tanah itu. Ia berkata, "Wahai Rasulullah, saya memperoleh tanah di Khaibar yang belum pernah saya peroleh harta yang lebih baik bagiku melebihi tanah tersebut. Apa perinta Engkau kepadaku mengenainya? "Nabi SAW menjawab, "Jika mau, kamu tahan pokoknya dan kamu sedekahkan hasilnya". ${ }^{30}$

Kedua hadis di atas merupakan dasar umum disyariatkannya wakaf dan juga dipakai oleh MUI dalam fatwa kebolehan wakaf uang. Hadis pertama mendorong manusia untuk menyisihkan sebagian rizkinya sebagai tabungan akhirat dalam bentuk sedekah jariyah. Uang merupakan sarana yang paling mudah untuk disedekahkan. Pada hadis kedua, dijadikan sebgai dasar hukum diperbolehkannya wakaf uang, karena menganggap bahwa wakaf uang memiliki hakikat yang sama dengan wakaf tanah, yakni harta pokoknya tetap dan hasilnya dapat dikeluarkan. Dengan mekanisme wakaf uang yang telah ditentukan, pokok harta akan dijamin kelestariannya dan hasil usaha atas penggunaan uang tersebut dapat dipakai untuk mendanai kepentingan umat. ${ }^{31}$

Meskipun ulama terdahulu berbeda pendapat tentang kebolehan wakaf tunai, namun ulama di zaman sekarang melihat manfaat wakaf tunai yang lebih luas sehingga membolehkan untuk mewakafkan uangnya. ${ }^{32}$ Berdasarkan beberapa dalil dan pendapat para ulama tersebut, MUI mengeluarkan fatwa tentang wakaf uang/tunai yang berisi: ${ }^{33}$

1. Wakaf uang (cash wakaf/waqf al-nuquæ) adalah wakaf yang dilakukan seseorang, kelompok orang, lembaga atau badan hukum dalam bentuk uang tunai.

2. Termasuk ke dalam pengertian uang adalah surat-surat berharga.

3. Wakaf uang hukumnya jawaz(boleh).

4. Wakaf uang hanya boleh disalurkan dan digunakan untuk hal-hal yang dibolehkan secara syar'i.

5. Nilai pokok wakaf uang harus dijamin kelestariannya, tidak boleh dijual, dihibahkan, dan atau diwariskan.

\footnotetext{
${ }^{27}$ Abu 'Isa Muhammad ibn 'Isa ibn Saurah Mutawafi, Sunan al-Turmuæhi $\ngtr$ Bairut: Daæal-Fikr, 2001), 88.

28 Abu Azam al Hadi, Hukum Perwakafan, 22.

${ }^{29} \mathrm{Abu}$ 'Isa Muhammad ibn 'Isa ibn Saurah Mutawafi, Sunan al-Turmuæhi>87.

${ }^{30}$ Sudirman Hasan, Wakaf Uang Perspektif Fiqih, 27.

${ }^{31}$ Ibid.

${ }^{32}$ Mardani, Aspek Hukum Lembaga Keuangan Syariah di Indonesia (Jakarta: Kencana, 2015), 304.

${ }^{33}$ Hasan Mansur Nasution, et al, Wakaf dan Pemberdayaan Umat (Jakarta: Sianar Grafika, 2010), 106.
} 


\section{Hikmah dan Manfaat Wakaf}

Allah memberikan manusia kemampuan dan karakter yang beraneka ragam. Dari keberagaman itu, kemudian timbul kondisi dan lingkungan yang berbeda di antara masingmasing individu, ada yang miskin, kaya, cerdas, bodoh, kuat, dan lemah, oleh karena itu Allah memberikan kesempatan kepada yang kaya menyantuni yang miskin, yang cerdas membimbing yang bodoh dan seterusnya. ${ }^{34}$ Dengan wakaf, kepincangan di antara kelompok si miskin dan si kaya dapat dipertipis dan dihilangkan terutama dalam bentuk wakaf yang dikhususkan kepada kelompok yang tidak mampu. Dengan wakaf itu juga, penyediaan sarana dan prasarana ibadah, pendidikan, seperti masjid, mushalla dan gedung-gedung pendidikan, akan lebih memungkinkan dengan potensi wakaf yang ada.

Selain itu dapat juga digunakan untuk membantu pihak yang miskin, baik miskin dalam artian ekonomi maupun tenaga. Di lain pihak, juga bertujuan untuk meningkatkan pembangunan keagamaan dan dapat membentuk jiwa sosial di tengah-tengah masyarakat. Mendidik manusia agar mempunyai tenggang rasa terhadap sesama, si kaya akan merasa bertanggung jawab terhadap orang yang miskin, sehingga akan terjalin hubungan ukhuwwah isla rriyyah dan menjadi persatuan umat. ${ }^{35}$

Ibadah wakaf tergolong pada perbuatan sunnah ini banyak sekali manfaat yang terkandung di dalamnya, antara lain:

1. Harta benda yang diwakafkan dapat tetap terpelihara dan terjamin kelangsungannya, tidak perlu khawatir barangnya hilang atau pindah tangan, karena secara prinsip barang wakaf itu tidak boleh di tasłłrrufkan apakah itu dalam bentuk menjual, dihibahkan atau diwariskan.

2. Pahala dan keuntungan bagi si waæif akan tetap mengalir walaupun dia sudah meninggal dunia, selama benda wakaf itu masih ada dan dapat dimanfaatkan. Oleh sebab itu benda wakaf diharuskan tahan lama (tidak boleh berkurang). Dalam keadaan seperti ini wakaf sebagai inventaris untuk meraih keuntungan pahala dari Allah.

3. Wakaf merupakan salah satu sumber dana yang sangat penting manfaatnya bagi kehidupan agama dan umat. Antara lain untuk pembinaan mental, spiritual, dan pembangunan segi fisik. ${ }^{36}$

4. Hikmah wakaf dapat berupa keuntungan-keuntungan seperti yang terdapat dalam wakaf ahli yang sesuai sekali dengan jiwa hukum Islam, yakni untuk menjaga pihak yang diberi wakaf (keluarga) agar tidak jatuh fakir miskin, dan menghindari dari kemungkinan permusuhan harta secara cepat atau tak terkendali yang berarti menghindarkan keluarga agar tidak jatuh fakir miskin. ${ }^{37}$

5. Wakaf berfugsi mewujudkan potensi dan manfaat ekonomi harta benda wakaf untuk kepentingan ibadah dan untuk memajukan kesejahteraan umum. ${ }^{38}$

Dengan demikian maka dapat dirumuskan secara sederhana beberapa hal keutamaan wakaf, sebagai berikut:

\footnotetext{
${ }^{34}$ Muhammad Abid Abdullah al-Kabisi, Hukum Wakaf, 83

35 Ibid.

${ }^{36}$ Abdul Halim, Hukum Perwakafan di Indonesia (Ciputat: Ciputat Perss, 2005), 40.

${ }^{37}$ Juhaya S. Praja, Perwakafan di Indonesia (Bandung: Yayasan Piara, 1995), 31.

38 Team Media, Undang-Undang Nomor 41 tahun 2004 tentang Wakaf (Media Centre, 2004), 165.
} 
1. Melalui wakaf dapat menumbuhkan sifat zuhud, dan melatih seseorang untuk saling membantu atas kepentingan orang lain.

2. Dapat menghidupkan lembaga-lembaga sosial keagamaan maupun kemasyarakatan untuk mengembangkan potensi umat.

3. Menanamkan kesadaran bahwa di dalam setiap harta benda itu meski telah menjadi milik seseorang secara sah, tetapi masih ada di dalamnya harta agama yang mesti diserahkan sebagaimana juga zakat.

4. Menyadarkan seseorang bahwa kehidupan di akhirlah memerlukan persiapan yang cukup, maka persiapan bekal itu di antaranya wakaf sebagai tabungan akhirat.

5. Keutamaan lain dapat menopang dan penggerak kehidupan sosial kemasyarakatan umat Islam, baik aspek ekonomi, sosial, budaya dan lainnya. ${ }^{39}$

\section{Sejarah Wakaf Tunai}

Dalam sejarah peradaban Islam dapat diketahui bahwa wakaf pertama kali dilakukan Rasulullah Muhammad SAW ketika membangun Masjid Quba di Madinah. Menurut versi yang berbeda, wakaf pertama adalah merupakan wakaf yang dilakukan Rasulullah SAW ketika setelah mengambil alih kepemilikan tujuh buah kebun milik seorang Mukhairiq (orang Yahudi yang terbunuh ketika perang uhud dan berpihak kepada muslim). Peristiwa wakaf ini kemudian diikuti oleh Umar ibn Khattab serta sahabat-sahabat yang lain. ${ }^{40}$

Dalam catatan sejarah Islam, wakaf uang/tunai ternyata sudah dipraktikkan sejak awal abad ke-2 Hijriyah. Diriwayatkan oleh Imam Bukhari bahwa Imam al-Zuhri (wafat $124 \mathrm{H}$ ), salah seorang tekemuka dan peletak tadwi al-hłıdił memfatwakan bolehnya mewakafkan uang, yaitu dinar dan dirham dalam rangka untuk pembangunan sarana dakwah, sosial dan pendidikan. Caranya adalah dengan menjadikan modal usaha dan menyalurkan keuntungannya kepada mawqus'alay ${ }^{41}$

Pada masa Dinasti Ayyubiyah di Mesir, perkembangan wakaf sangat menggembirakan. Pada masa ini, wakaf tidak hanya terbatas pada benda tidak bergerak, tapi juga benda bergerak, semisal wakaf tunai. Tahun 1178 M/572 H, dalam rangka mensejahterakan ulama dan kepentingan Mazhab Sunni, Salahuddin al-Ayyubi menetapkan kebijakan bahwa orang Kristen yang datang ke Iskandar untuk berdagang wajib membayar bea cukai. Tidak ada penjelasan, orang Kristen yang datang dari Iskandar itu membayar bea cukai dalam bentuk barang atau uang? Namun lazimnya bea cukai dibayar dengan uang. Uang hasil pembayaran bea cukai itu dikumpulkan dan diwakafkan kepada para fuqaha $>$ dan para keturunannya. ${ }^{42}$

Dinasti Mamluk juga mengembangkan wakaf dengan pesatnya, apa saja boleh diwakafkan dengan syarat dapat diambil manfaatnya. Tetapi yang banyak diwakafkan pada masa itu adalah tanah pertanian dan bangunan, seperti gedung perkantoran, penginapan dan tempat belajar. Juga, pada masa Dinasti Mamluk terdapat hamba sahaya (budak) yang diwakafkan untuk merawat lembaga-lembaga agama. Misalkan mewakafkan budak untuk memelihara masjid dan madrasah. Hal ini dilakukan pertama kali oleh penguasa Dinasti

\footnotetext{
${ }^{39}$ Abdul Halim, Hukum Perwakafan, 44-45.

${ }^{40}$ Faisal Haq, Hukum Perwakafan, 88-89.

${ }^{41}$ Rozalinda, Ekonomi Islam, 227.

${ }^{42}$ Dikektorat Pemberdayaan Wakaf, Derektorat Jendral Bimbingan Masyarakat Islam, Pedoman Pengelolaan Wakaf Tunai (Jakarta: t.p., 2007), 12.
} 
Usmani ketika menaklukkan Mesir, Sulaiman Basya yang mewakafkan budaknya untuk merawat masjid. ${ }^{43}$

Dinasti Mamluk menjadikan wakaf sebagai salah satu tulang punggung roda perekonomian negara, mereka mengeluarkan kebijakan dengan membuat peraturan perundang-undangan tentang wakaf yang dimulai sejak Raja al-Dzahir Bibers al-Bandaq (1260-1277 M). Dengan undang-undang tersebut Raja al-Dzahir memilih hakim untuk mengurusi wakaf dari masing-masing mazhab yang ada dan digunakan untuk kepentingan masyarakat secara umum, termasuk memelihara fasilitas yang ada di Kota Mekkah dan Madinah. $^{44}$

Penyebarluasan peraturan perwakafan ini semakin intensif dan semakin mudah dilakukan pada masa Kerajaan Ottoman (Turki Usmani). Hal tersebut dimungkinkan karena kekuasaan kerajaan Turki Usmani menyebar luas hingga mampu menguasai sebagian besar wilayah Arab. Kekuasaan politik yang diperoleh Turki Usmani ini secara otomatis mempermudah tersosialisasinya peraturan perundang-undangan perwakafan yang dikeluarkan pada tahun $1280 \mathrm{H}$ yang mengatur tentang tata cara pencatatan wakaf, sertifikat wakaf, cara pengelolaan wakaf, upaya mencapai tujuan wakaf dan melembagakan wakaf dalam upaya realisasi wakaf dari sisi administrasi dan perundang-undangan. ${ }^{45}$

Di era modern ini, wakaf uang atau wakaf tunai menjadi populer berkat sentuhan piawai M. A. Mannan dengan berdirinya sebuah lembaga yang ia sebut Social Investment Bank Limited (SIBL) di Bangladesh. SIBL memperkenalkan produk sertifikat wakaf uang pertama kali di dunia. Lembaga ini mengumpulkan dana dari para aghniya> (orang kaya) untuk dikelola secara professional sehingga menghasilkan keuntungan yang dapat disalurkan kepada para mustad\}afił (orang fakir miskin). ${ }^{46}$

Di Bangladesh, wakaf uang telah dikelola oleh Social Investment Bank Limited (SIBL) dengan mengembangkan pasar modal sosial (the valutary capital market). Instrumentinstrumen keuangan Islam yang telah dikembangkan, antara lain adalah Surat Obligasi Pembangunan Perangkat Wakaf (Waqf Properties Development Bond), Sertifikat Wakaf Uang (Cash Waqf Deposit Certificate), Sertifikat Wakaf Keluarga (Family Waqf Certificate), Obligasi Pembangunan Perangkat Masjid (Mosque Properties Development Bond), Saham Komunitas Masjid (Mosque Community Share), Sertifikat Qard\}al-H\&lsan (Quard-e-Hasana Certificate), Sertifikat Pembayaran Zakat (Zakat/Ushar Payment Certificate), dan Sertifikat Simpanan haji (Hajj Saving Certificate). Terobosan ini menunjukkan bahwa wakaf uang dapat memberikan konstribusi nyata untuk peningkatan kesejahteraan umat. ${ }^{47}$

Wakaf terus dilaksanakan di negara-negara Islam hingga sekarang, tidak terkecuali Indonesia. Hal ini tampak dari kenyataan bahwa lembaga wakaf yang berasal dari agama Islam itu telah diterima menjadi hukum adat bangsa Indonesia sendiri. Dan juga di Indonesia terdapat banyak benda wakaf, baik wakaf benda bergerak atau benda tidak bergerak. ${ }^{48}$

\footnotetext{
${ }^{43}$ Ibid., 13.

${ }^{44}$ Faisal Haq, Hukum Perwakafan, 90.

${ }^{45}$ Ibid., 90.

${ }^{46}$ Sudirman Hasan, Wakaf Uang Perspektif Fiqih, 23-24.

${ }^{47}$ Ibid., 24.

${ }^{48}$ Dikektorat Pemberdayaan Wakaf, Derektorat Jendral Bimbingan Masyarakat Islam, Pedoman Pengelolaan Wakaf, 15.
} 
Di negara-negara Islam lainnya, wakaf menjadi perhatian yang serius, sehingga wakaf menjadi amal sosial yang mampu memberikan manfaat kepada masyarakat umum. Wakaf akan terus mengalami perkembangan dengan berbagai inovasi yang signifikan seiring dengan perubahan zaman, semisal bentuk wakaf tunai, wakaf HAKI (Hak Kekayaan Intelektual) dan lain-lain. ${ }^{49}$

\section{Pendapat Para Ulama Tentang Wakaf Tunai}

Penggunaan wakaf tunai telah lama dikenal dalam pemerintahan Islam, tetapi hukum mewakafkan uang tunai merupakan masalah yang masih diperdebatakan di kalangan ulama fikih. Beberapa sumber menyebutkan bahawa wakaf uang/tunai telah dipraktikkan oleh masyarakat yang menganut Mazhab Hanafi. ${ }^{50}$ Imam Bukhari mengungkapkan bahwa Imam al-Zuhri berpendapat bahawa dinar dan dirham (keduanya mata uang yang berlaku di Timur Tengah) boleh diwakafkan. Caranya adalah dengan menjadikan dinar dan dirham itu sebagai modal usaha (dagang), kemudian menyalurkan keuntungannya sebagai wakaf.

Wahbah al-Zuhayli juga mengungkapkan bahwa Mazhab Hanafi membolehkan wakaf tunai sebagai pengecualian atas dasar istihła bi al- 'urfi, karena sudah banyak dilakukan oleh masyarakat. Madzhab Hanafi memang berpendapat bahwa hukum yang ditetapkan berdasarkan 'urf (adat kebiasaan) mempunyai kekuatan yang sama dengan hukum yang ditetapkan berdasarkan nas\}(teks). Berikut adalah dasar argumentasi Mazhab Hanafi yang diriwayatkan oleh Abdullah ibn Mas'ud: ${ }^{51}$

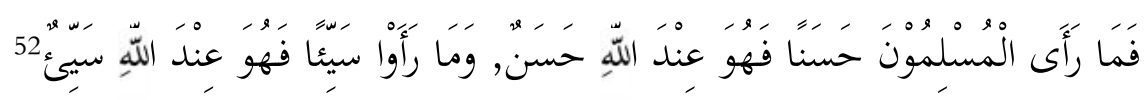

"Apa yang dipandang baik oleh kaum muslimin, maka dalam pandangan Allah adalah baik, dan apa yang dipandang buruk oleh kaum muslimin maka dalam pandangan Allah pun buruk. (Musnad Ahmad)". 53

Cara melakukan wakaf tunai menurut Mazhab Hanafi ialah dengan menjadikannya

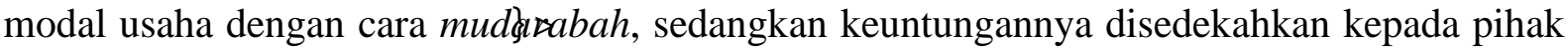
wakaf. ${ }^{54}$ Pendapat ini didukung oleh Ibn Jibrin salah satu ulama modern, bahwa wakaf tunai harus diberdayakan sehingga mampu memberikan kemudahan dalam membantu orang-orang yang secara ekonomi kurang beruntung. ${ }^{55}$

Sedangkan menut al-Bakri, Madzhab Syafi'i tidak membolehkan wakaf tunai karena dinar dan dirham (uang) akan lenyap ketika dibayarkan sehingga tidak ada lagi wujudnya. ${ }^{56}$ Adapun alasan lain yang tidak membolehkan wakaf tunai oleh ulama Syafi'iyah antara lain: ${ }^{57}$

\footnotetext{
49 Ibid.

${ }^{50}$ Ibid.

${ }^{51}$ Ibid., 4.

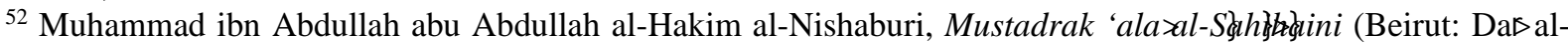
Kitabal-'Alamiah, 1990), 37.

${ }^{53}$ Sudirman Hasan, Wakaf Uang Perspektif Fiqih, 28.

${ }^{54}$ Dikektorat Pemberdayaan Wakaf, Derektorat Jendral Bimbingan Masyarakat Islam, Pedoman Pengelolaan Wakaf, 5.

${ }^{55}$ Sudirman Hasan, Wakaf Uang Perspektif Fiqih, 28.

56 Dikektorat Pemberdayaan Wakaf, Derektorat Jendral Bimbingan Masyarakat Islam, Pedoman Pengelolaan Wakaf, 5.
} 
1. Bahwa uang zatnya bisa habis dengan sekali pakai. Uang hanya bisa dimanfaatkan dan dibelanjakan sehingga bendanya lenyap. Menurut mereka kenapa benda yang bergerak tidak dibolehkan untuk diwakafkan karena salah satu syarat wakaf adalah permanen, sedangkan yang bergerak itu tidaklah permanen.

2. Bahwa uang itu diciptakan sebagai alat tukar, bukan untuk ditarik manfaatnya dengan mempersewakan zatnya.

Tapi sebagian ulama Mazhab Syafi'i berpendapat bahwa boleh mewakafkan uang sesuai dengan hadis yang diriwayatkan oleh Abu Tsaur:

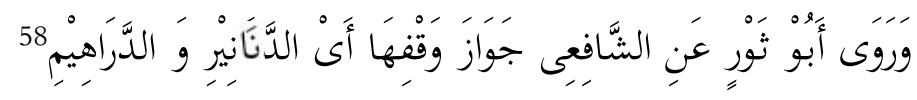

“Abu Thaur meriwayatkan dari Imam Syafi'i tentang dibolehkannya wakaf dinar dan dirham".

Sedangkan ulama pengikut Mazhab Maliki berpendapat boleh mewakafkan benda bergerak maupun benda tidak bergerak. Wahbah al-Zuhayli menjelaskan bahwa ulama Mazhab Maliki membolehkan wakaf makanan, uang dan benda bergerak lainnya, Wahbah alZuhayli juga menjelaskan bahwa wakaf uang dapat diqiyaskan atau dianalogikan dengan baju perang dan binatang, sebab terdapat kesamaan 'illat antara keduanya, yaitu sama-sama benda bergerak dan tidak kekal yang mungkin rusak dalam jangka waktu tertentu. Hal ini menunjukkan bahwa Imam Maliki membolehkan wakaf untuk jangka waktu tertentu. Namun apabila wakaf uang itu dikelola secara profesional memungkinkan uang yang diwakafkan akan kekal selamanya. ${ }^{59}$ Begitu juga dengan Mazhab Hambali, ia memperbolehkan wakaf dalam bentuk uang tunai, baik dirham maupun dinar. ${ }^{60}$

\section{Sertifikat Wakaf Tunai}

Pada umumnya masyarakat mengenal wakaf berupa properti seperti tanah dan bangunan, namun demikian dewasa ini telah disepakati secara luas oleh para ulama bahwa salah satu bentuk wakaf dapat berupa uang tunai. Secara umum definisi wakaf tunai adalah penyerahan aset wakaf berupa uang tunai yang tidak dapat dipindah tangankan dan dibekukan untuk selain kepentingan umum yang tidak mengurangi ataupun menghilangkan jumlah pokoknya (substansi esensial wakaf). ${ }^{61}$

Sertifikat wakaf tunai merupakan semacam dana abadi yang diberikan oleh individu maupun lembaga wakaf yang mana keuntungan dari pengelolaan dana tersebut akan digunakan untuk kesejahteraan masyarakat. Secara teknis, sertifikat wakaf tunai ini dapat dikelola oleh suatu badan investasi sosial tersendiri seperti halnya Social Investment Bank

\footnotetext{
${ }^{57}$ Fitra Hayani, Wakaf Tunai dalam Perspektif Ulama Fiqih (Skripsi--UIN Syarif Hidayatullah Jakarta, 2007), 45-56.

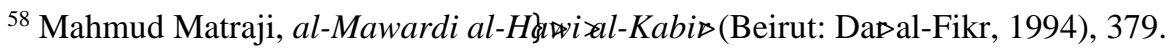

${ }^{59}$ As-Syarif, "Wakaf", dalam http://duniailmuweb.blogspot.com/2012/05/wakaf.html?m=1 diakses pada 29 Mei 2012.

${ }^{60}$ M. Nur Rianto al Arif, Lembaga Keuangan Syariah, 417.

${ }^{61}$ Muhammad Abid Abdullah al-Kabisi, Hukum Wakaf, 7.
} 
Limited (SIBL) di Bangladesh atau dapat juga menjadi salah satu produk dari institusi/perbankan syariah yang ada. ${ }^{62}$

Untuk lebih jelasnya tujuan sertifikat wakaf tunai adalah sebagai berikut:

1. Membantu dalam pemberdayaan tabungan sosial.

2. Melengkapi jasa perbankan sebagai fasilitator yang menciptakan wakaf tunai serta membantu pengelolaan wakaf yang mentransformasi tabungan sosial menjadi modal sosial.

3. Keuntungan pengelolaannya untuk masyarakat miskin.

4. Menciptakan kesadaran di kalangan orang-orang kaya mengenai tanggung jawab sosial mereka terhadap masyarakat miskin.

5. Untuk membantu mengembangkan sumber modal sosial.

6. Untuk membantu pengembangan negara secara umum dan untuk menciptakan integrasi yang unik antara keamanan sosial dan kedamaian sosial. ${ }^{63}$

\section{Manajemen Dana Wakaf Uang}

Secara historis, cara yang banyak ditempuh dalam manajemen wakaf, sesuai dengan informasi dalam buku-buku fikih, adalah dengan jalan mempersewakan harta wakaf. Hal ini sejalan dengan kenyataannya bahwa kebanyakan harta wakaf yang terjadi pada saat itu adalah dalam bentuk al-'iqa (harta tak bergerak, seperti lahan pertanian dan bangunan). Ada beberapa bentuk penyewaan yang terdapat dalam konsep fikih: ${ }^{64}$

1. Sewa biasa (ijaðah). Dengan pertimbangan kemaslahatan harta wakaf, para ulama mazhab yang empat sepakat membolehkan mempersewakan harta wakaf, meskipun mereka berbeda dalam beberapa hal.

2. Akad sewa menyewa ganda ('aqd al-ija aatain). Akad sewa ganda ini dilakukan untuk mengatasi kekurangan modal untuk membangun bangunan di atas sebidang tanah wakaf. Untuk memperoleh modal, diadakan kontrak sewa dengan seorang penyewa untuk jangka waktu lama, dengan dua tingkat sewa menyewa. Sewa pertama dibayar lebih dulu sejumlah yang memungkinkan untuk membangun bangunan dimaksud. Sedangkan sewa kedua merupakan sewa bulanan dengan harga yang lebih murah yang harus dibayar selama menghuni rumah. Sewa kedua ini masih diperlukan untuk menghindarkan kemungkinan ada klaim dari penyewa bahwa rumah itu telah dibelinya.

3. Al-h H $_{k} r u$, yaitu sebuah akad sewa menyewa tanah wakaf untuk masa waktu yang lama, serta memberi hak kepada penyewa untuk mendiami tanah itu, untuk membangun atau bercocok tanam di atas lahan pertanian dan memberinya hak untuk memperpanjang masa sewa setelah kontrak pertama habis, selama ia masih mampu membayar sewa pasaran.

4. Al-marshid, yaitu sebuah kesepakatan dengan calon penyewa yang bersedia meminjami $n a z \gg$ sejumlah dana untuk memperbaiki bangunan wakaf sebagai hutang yang kemudian akan dibayar dengan sewa harta wakaf itu sendiri.

\footnotetext{
${ }^{62}$ Ahmad Djunaidi dan Thobieb al-Asyhar, Menuju Era Wakaf Produktif (Jakarta: Mitra Abadi Press, 2006), 104.

$63 \mathrm{http}: / /$ www.sabilulhuda.org/index.php?option=com_content\&view=article\&id=64:manajemen-efektif-danawakaf-produktif\&catid=42: mutiara-hikmah\&Itemid=73.

${ }^{64}$ Ibid.
} 
5. Pengembangan hasil sewa wakaf dengan membelikannya kepada benda yang bisa menghasilkan, misalnya dengan memodali pembangunan gedung yang kemudian dapat disewakan lagi.

6. Dengan melakukan kerja sama dalam pengelolaan lahan pertanian wakaf di samping dengan mempersewakannya kepada pihak yang punya modal, juga mungkin dengan kerjasama muza®a'ah.

Informasi manajeman di atas bisa dijadikan sebagai rujukan untuk asset wakaf dalam bentuk harta tidak bergerak agar bisa produktif. Sedangkan untuk manajemen dana wakaf uang adalah dengan jalan menginvestasikannya. Baik dengan prinsip bagi hasil (mudglırabah dan mushaæakah), sewa (ijaðah), maupun murałahłh. Berikut ini akan diuraikan bentukbentuk investasi yang dapat dilakukan nadhir wakaf terhadap wakaf uang: ${ }^{65}$

1. Investasi Mudłrabah

Lembaga keuangan syariah telah menawarkan produk investasi syariah. Produk ini merupakan salah satu alternatif yang bisa digunakan untuk mengembangkan harta wakaf. Salah satu contoh yang bisa dilakukan oleh naz $\}^{\gg}>$ dengan produk ini adalah membangkitkan sektor usaha kecil dan menengah dengan memberikan modal usaha kepada petani, pedagang kecil dan menengah (UKM). Dalam hal ini pengelola wakaf uang berperan sebagai statb al-mabyang menyediakan dana $100 \%$ dari usaha/proyek dengan sistem bagi hasil, sementara itu pengusaha atau petani adalah sebagai mudłtrib yang memutarkan dana tersebut. Hasil keuntungan yang diperoleh dibagi bersama antara

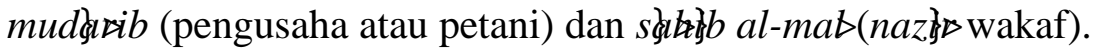

2. Investasi Mushaæakah

Investasi mushaæakah ini hampir sama dengan mudlabah. Yang membedakan dalam produk lembaga keuangan syariah ini adalah dalam hal modal dan risikonya. Kalau mudgrabah modalnya hanya dari salah satu pihak yang dalam hal ini dinamakan słat ib almat. Sedangkan dalam mushaðakah modal diperoleh dari keduanya (semua yang berakad). Demikian juga dengan risiko, kalau mudłrabah hanya di tanggung słtetb almał, sedangkan dalam mushaðakah ditanggung keduanya (semua yang berakad). Investasi ini memberi peluang bagi pengelola wakaf untuk menyertakan modalnya pada sektor usaha kecil menengah yang dianggap memiliki kelayakan usaha namun kekurangan modal untuk mengembangkannya.

3. Investasi Muraßahłh

Dalam investasi muraßahłh membeli peralatan dan material yang diperlukan seseorang atau pembeli melalui kontrak murałahłh. Melalui investasi ini, pengelola wakaf dapat mengambil keuntungan dari selisih harga pembelian dan penjualan. Dari investasi ini, pengelola wakaf dapat membantu pengusaha-pengusaha kecil yang membutuhkan alat-alat produksi.

Sedangkan Munzir Qahaf menawarkan cara pengelolaan wakaf uang sebagai berikut: ${ }^{66}$

1. Badan wakaf (pengelola wakaf) menerima wakaf uang. Dari penerimaan wakaf uang tersebut kemudian dana wakaf digunakan untuk mendanai proyek tertentu dan

\footnotetext{
${ }^{65}$ Rozalinda, Ekonomi Islam, 228.

${ }^{66}$ Munzir Qahar, al-Waqf al-Islaæriy Tatłwwwuruhu> Idaฉatuhu> Tanmiyatuhu> terj. Muhyidin Mas Ridha, (Jakarta: Khalifa, 2000), 199-201.
} 
keuntungan deberikan kepada mauqu户 'alayh. Dalam hal ini, badan wakaf adalah naz $\gg$ wakaf atas uang yang diwakafkan. Di samping itu, badan wakaf ini juga sebagai investor. Badan wakaf bisa secara langsung menginvestasikan kepada suatu perusahaan atau menginvestasikan kepada bank syariah atau lembaga keuangan syariah lainnya berdasarkan prinsip mudłrabah atau ijazah sesuai dengan ketentuaan syariat.

2. Bentuk wakaf yang dilakukan dengan cara waæif sebagai pihak yang menginvestasikan uang, maka wakaf uang diinvestasikan dalam bentuk wadi $\gg$ ah di lembaga keuangan syariah. Dalam hal ini, wałif berperan langsung sebagai nazł atas uang yang diwakafkannya dengan tugas menginvestasikan dana wakaf dan mencari keuntungan dari uang yang diwakafkan. Kemudian hasilnya diserahkan kepada mauqu^ 'alayh. Bentuk seperti ini juga bisa digunakan pada tabungan wakaf di bank syariah. Tabungan dari masyarakat yang berpenghasilan tinggi dapat dimanfaatkan melalui penukaran sertifikat wakaf tunai. Pendapatan yang diperoleh dari pengelolaan wakaf uang dapat dibelanjakan ke berbagai tujuan, seperti kesehatan, pendidikan termasuk memelihara harta wakaf. Sebagai nazł $\gg$, wa if dapat memindahkan uang wakaf dari bank syariah satu ke bank syariah lain atau dari bentuk investasi investasi wadi’ah ke investasi mud lababah.

3. Bentuk wakaf investasi dipergunakan untuk membangun proyek wakaf produktif. Kemudian hasilnya diberikan kepada mauqus 'alayh. Pengelolaan uang dengan cara seperti ini perlu membentuk panitia pengumpul dana agar membangun wakaf sosial. Apabila kaum muslimin membutuhkan dana untuk membangun masjid dibentuk panitia pengumpul dana untuk pembangunan masjid. Begitu pula dengan pembangunan sarana umum dan sosial lainnya dibentuk panitia pengumpul dana untuk pembangunan sarana tersebut. dana yang terkumpul kemudian digunakan untuk membangun sarana fisik tersebut secara hukum telah berubah menjadi wakaf sejak diberikan kepada panitia pelaksana proyek pembangunan.

\section{Urgensi dan Peran Wakaf Uang dalam Perekonomian}

1. Urgensi wakaf uang dalam perekonomian

a. Terhadap waæif

Urgensi wakaf uang terhadap waæif adalah seorang wałif tidak perlu menunggu memiliki uang yang banyak untuk membeli tanah untuk diwakafkan. Karena wakaf uang tidak ditentukan batas dan jumlahnya. Hal ini berbeda dengan wakaf dengan benda tidak bergerak seperti tanah. Seorang wałif harus menjadi orang kaya dulu atau mempunyai uang banyak dulu agar bisa membeli tanah. Kalau seorang itu tidak mempunyai uang banyak maka selamanya dia tidak akan bisa melakukan wakaf. Padahal wakaf itu merupakan perbuatan yang sangat dianjurkan karena akan mengalirkan pahala terus menerus meskipun waæifnya sudah meninggal. Maka dengan wakaf uang yang tidak ada batas jumlahnya tadi akan mendorong masyarakat untuk berwakaf sesuai dengan kemampuannya sehingga jumlah waæif dan jumlah dana wakaf akan semakin banyak.

b. Terhadap pertumbuhan ekonomi secara makro

1) Meningkatkan pertumbuhan ekonomi 
Dana terkumpul dari wakaf uang yang dialokasikan untuk investasi bisnis bisa diyakini mampu meningkatkan pertumbuhan ekonomi suatu negara, yaitu dengan mentansformasikan tabungan masyarakat menjadi modal investasi. Hal ini dapat digambarkan melalui ilustrasi berikut, yaitu jika ada 25 juta dari 250 juta umat Islam Indonesia mewakafkan uangnya sebesar 10 ribu rupiah, maka akan diperoleh dana wakaf sebesar 250 milyar rupiah yang siap untuk di investasikan. Jika dana itu dititipkan di bank syariah dengan bagi hasil $10 \%$ per tahun, maka pada akhir tahun sudah ada dana segar yang yang siap dimanfaatkan sebesar 25 milyar rupiah. Perhitungan ini baru sebesar 10 ribu rupiah dan satu kali wakaf. Lantas bagaimana jika yang mewakafkan sebanyak 200 juta orang dengan jumlah wakaf di atas 10 ribu rupiah dan dilakukan berulang-ulang untuk beberapa periode, karena wakaf dapat dilakukan kapan saja dan berapapun. Tentulah jumlah wakaf itu akan terkumpul dengan jumlah sangat besar dan sangat potensial untuk menjadi sumber dana investasi bagi pengembangan ekonomi umat.

2) Pemerataan pertumbuhan ekonomi

Sebagaimana gambaran ilustrasi di atas, jika 25 milyar sebagai hasil menginvestasikan dana wakaf sebesar 250 milyar, betapa banyak orang miskin akan mendapatkan manfaat dari dana tersebut. Melalui modal kerja, menyantuni anak yatim dan panti asuhan, memperbaiki sekolahan, bahkan mendirikan balai kesehatan. Wakaf uang tidak hanya meningkatkan pertumbuhan ekonomi, tetapi juga mampu menciptakan pemeratan pendapatan terutama bagi masyarakat yang semula tidak memiliki peluang usaha menjadi mendapatkan peluang usaha. Bagi masyarkat yang semula tidak mempunyai pendapatan, berubah menjadi memiliki pendapatan.

c. Terhadap lembaga keuangan syariah penerima titipan dana wakaf

Jika hasil penghimpunan dana wakaf dititipkan kepada lembaga keuangan syariah dan dikelola dengan baik, maka akan memberikan pengaruh positif bagi pengembangan lembaga keuangan syariah. Karena dengan penitipan tersebut akan menambah perolehan pendapatan dari penghimpunan dana bank yang kemudian oleh bank disalurkan kepada pihak ketiga yang pada akhirnya bisa menambah penghasilan bank.

d. Terhadap stabilitas politik dan ekonomi

Jika potensi wakaf uang dalam meningkatkan pertumbuhan dan pemerataan ekonomi dapat diwujudkan, maka hal ini akan mampu menjaga stabilitas politik. Investasi dana wakaf melalui sektor riil akan mengarah pada keseimbangan antara uang wakaf yang terhimpun dan sektor riil yang membutuhkan dana untuk berproduksi menghasilkan barang. Jika diinvestasikan melalui perbankan dengan sistem bagi hasil maka akan dapat mengantisipasi gejolak ekonomi akibat gejolak bunga yang berlebihan. Hasil dari pengelolaan dana wakaf dapat menjaga stabilitas politik akibat ketidak mampuan pemerintah menciptakan pertumbuhan ekonomi, yakni dengan meningkatkan taraf kehidupan masyarakat yang meliputi pendapatan 
yang lebih tinggi dan tersedianya lapangan kerja. Keadan ini akan dapat mengurangi beban APBN pemerintah dan menambah devisa negara. ${ }^{67}$

2. Peran wakaf uang dalam perekonomian

Dalam rangka meningkatkan kesejahteraan masyarkat, pemberdayaan wakaf uang merupakan salah satu alternatif yang sangat baik. Indonesia yang merupakan negara berpenduduk muslim paling besar wakaf uang sangat berpotensi untuk dilakukan. Apalagi wakaf uang bisa menyentuh seluruh lapisan masyarakat. Semua umat Islam dapat mewakafkan sebagian uangnya menurut yang ia kehendaki tanpa harus menunggu menjadi orang kaya terlebih dahulu. Jika terdapat satu juta orang Islam saja yang mewakafkan uangnya sebesar 50 ribu rupiah per bulan, maka akan diperoleh dana wakaf 50 miliar rupiah perbulan (600 miliar rupiah per tahun). Dan jika dana tersebut diinvestasikan dengan return 10\% maka akan diperoleh penambahan dana wakaf 5 miliar rupiah per bulan (60 miliar rupiah per tahun). Sedangkan dalam masalah distribus hasil wakaf dapat dinikmati oleh seluruh lapisan masyaarakat baik yang kaya atau yang miskin. Karena wakaf berbeda dengan zakat yang hanya diperuntukkan kepada delapan asłaßsebagaimana yang disebutkan dalam al-Quran (surat al-Taubah ayat 60).

Melalui wakaf uang, aset-aset wakaf seperti tanah kosong yang tidak produktif dapat dimanfaatkan melalui pembangunan toko atau lainnya yang kemudian hasilnya dapat disalurkan untuk masyarakat. Dengan potensi dana yang cukup besar sebagaimana ilustrasi di atas, cara pengelolaan wakaf seperti ini akan dapat mengatasi berbagai masalah yang terjadi di masyarakat terutama bagi masyarakat yang kekurangan dana. Bagi masayarakat yang tidak punya modal untuk usaha, mereka pun bisa meminjam dari lembaga tersebut atau bahkan bisa dibagihasilkan melalui pinjaman tersebut.

Melihat potensi yang begitu besar perlu adanya sosialisasi wakaf uang ini kepada masyarkat agar wakaf uang ini bisa berjalan secara optimal. Untuk mewujudkan tersosialisasinya wakaf uang dengan baik, perlu dibentuk lembaga wakaf tunai dimulai dari lingkungan terkecil, seperti di masjid, musholla, madrasah, pesantren atau lembaga swadaya yang ada. Setelah terbentuknya lembaga tersebut maka akan muncul strategistrategi tertentu untuk mendapatkan dana wakaf banyak yang akan dimunculkan oleh lembaga misalnya strategi jemput bola dengan mendatangi ke rumah-rumah warga. ${ }^{68}$

\section{Upaya Ekstensifikasi Sumber Wakaf}

Adanya pengembangan wakaf uang sebagaimana dijelaskan di atas, menunjukkan adanya upaya yang terus menerus untuk memaksimalkan sumber dana wakaf. Karena semakin banyak dana wakaf yang dapat dihimpun, berarti semakin banyak pula kebaikan yang mengalir kepada pihak yang berwakaf. Dengan demikian, pendapat ulama yang membolehkan berwakaf dalam bentuk uang, membuka peluang bagi aset wakaf untuk memasuki berbagai macam usaha investasi seperti syirkah, mud la babah dan lainnya. ${ }^{69}$

Dari berbagai pandangan ulama tentang wakaf tunai tersebut menunjukkan adanya kehati-hatian para ulama dalam memberikan fatwa sah atau tidak sahnya suatu praktek wakaf.

\footnotetext{
${ }^{67}$ Rozalinda, Ekonomi Islam, 236.

${ }^{68}$ Ibid., 237.

${ }^{69}$ Ahmad Djunaidi dan Thobieb al-Asyhar, Menuju Era Wakaf, 102.
} 
Hal ini disebabkan harta wakaf adalah harta amanah yang terletak di tangan naz harta amanah, maka naz $\gg$ hanya boleh melakukan hal-hal yang mendatangkan kemaslahatan bagi harta wakaf. Berdasarkan pertimbangan ini, maka yang perlu dipikirkan adalah bagaimana langkah yang mungkin mengantisipasi adanya resiko kerugian yang akan mengancam eksistensi dan kesinambungan aset wakaf? Untuk menjawab pertanyaan di atas dalam hal resiko kerugian adalah dengan melibatkan lembaga penjamin syariah bagi yang pengelolanya lembaga keuangan syariah, sedangkan jika pengelolanya selain lembaga keuangan syariah maka alternatifnya adalah melibatkan perusahaan asuransi syariah. ${ }^{70}$

\section{Wakaf Sebagai Dana Publik}

Pengelolaan dana wakaf uang merupakan pengelolaan dana publik yang manfaatnya pun akan disalurkan kembali kepada publik. Oleh karena itu, dalam pengelolaannya budaya transparansi serta akuntabilitas merupakan satu faktor yang harus diwujudkan. pentingnya budaya ini ditegakkan karena di satu sisi hak wąif atas aset (wakaf tunai) telah hilang, sehingga dengan adanya budaya pengelolaan yang profesional, transparansi serta akuntabilitas, maka beberapa hak konsumen (waæif) seperti:

1. Hak atas informasi yang benar, jelas dan jujur mengenai kondisi dan jaminan barang dan/atau jasa.

2. Hak untuk didengar pendapat dan keluhannya atas barang dan/atau jasa yang digunakan.

3. Hak untuk mendapatkan pembinaan dan pendidikan konsumen sedikit banyak akan dapat dipenuhi. ${ }^{71}$

\section{Kesimpulan}

Berdasarkan pada kajian di atas dapat disimpulkan bahwa untuk meningkatkan kesejahteraan masyarakat, wakaf uang merupakan aset yang sangat potensial dan perlu diberdayakan. Oleh karena itu hal-hal yang perlu dilakukan adalah:

Pertama, merubah pemahaman konsepsi fikih wakaf yang selama ini diyakini oleh masyarakat. Karena pada umumnya masyarakat Indonesia selama ini pemahaman wakafnya terbatas pada wakaf benda tak bergerak. Kedua, sosialisasi tentang keberadaan wakaf uang beserta konsepnya kepada masyarakat. Mulai dari manfaat wakaf uang, pengelolahan wakaf uang dan termasuk kemudahan wakif dalam berwakaf yang tidak perlu menjadi tuan tanah terlebih dahulu. Ketiga, sertifikat wakaf uang hendaklah tidak dengan nilai nominal yang besar setidaknya ada pecahan 20 ribu, 10 ribu atau bahkan 5 ribu. Hal ini dimaksudkan agar umat Islam yang ekonominya menengah ke bawah bisa berpartisipasi di wakaf uang ini. Dengan cara semacam ini juga akan meningkatkan perolehan dana wakaf.

Keempat, keuntungan yang didapat dari usaha produktif dana wakaf hendaknya segera disalurkan kepada masyarakat yang berhak, jangan sampai keuntungan itu di tahan berlarutlarut pada lembaga. Karena hal ini berkaitan dengan kepercayaan wakif dan agar masyarakat secepatnya tahu tentang manfaat dari wakaf uang. Kelima, penyaluran keuntungan kepada fakir miskin hendaknya tidak hanya berupa uang, akan tetapi fakir miskin tersebut dibuatkan

\footnotetext{
${ }^{70}$ Ibid., 104.

71 http://www.sabilulhuda.org/index.php?option=com_content\&view=article\&id=64:manajemen-efektif-danawakaf-produktif\&catid=42: mutiara-hikmah\&Itemid=73
} 
usaha yang bisa mengangkat perekonomian mereka. Tujuan dari penyaluran semacam ini dikarenakan rata-rata mereka menjadi miskin disebabkan mereka tidak mempunyai pekerjaan yang menghasilkan pendapatan tetap. Sehingga dengan pembuatan usaha tersebut diharapkan mereka kemudian mempunyai pendapatan sendiri dan tidak menjadi miskin permanen. Keenam, hendaklah pengelolaan wakaf uang tidak hanya pada lembaga keuangan syariah tetapi diperbanyak di lingkungan masyarakat seperti masjid, mushalla, madrasah atau lembaga swadaya masyarakat, meskipun lembaga tersebut bekerja sama dengan lembaga keuangan syariah. Dengan cara semacam ini akan mempermudah jangkauan masyarakat dan bisa menambah jumlah partisipasi masyarakat dalam berwakaf.

\section{Daftar Rujukan}

al-Arif, M. Nur Rianto. Lembaga Keuangan Syariah. Bandung: CV. Pustaka Setia, 2012.

al-Hadi, Abu Azam. Hukum Perwakafan dalam Islam dan di Indonesia. Jember: Pena Salsabila, t.th.

al-Kabisi, Muhammad Abid Abdullah. Hukum Wakaf. Jakarta: Dompet Dhuafa Republika dan Ilman, 2004.

al-Qardhawi, Yusuf. Hukum Zakat. Jakarta: Pustaka Utera Antar Nusa, 1993.

al-Shiddieqy, M.Hasbi. Falsafah Hukum Islam. Jakarta: Bulan Bintang, 1975.

al-Zuhayli, Wahbah. Zakat Kajian Berbagai Mazhab. terj. Agus Efendy dan Bahruddin Fanany. Bandung: Rosdakarya, 1997.

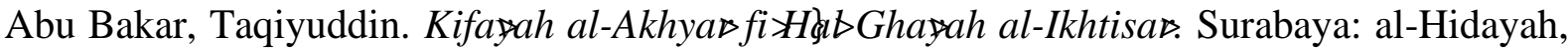
t.th.

Ali, Daud Muhammad. Sistem Ekonomi Islam, Zakat dan Wakaf. Jakarta: UI Press, 1998.

Departemen Agama RI. Al-Quran dan Terjemah. Surabaya: CV. Fajar Mulya, 2009.

Direktorat Pemberdayaan Wakaf-Dirjen Bimbingan Masyarakat Islam-Depag, Proses Lahirnya Undang-Undang Nomor 41 Tahun 2004 tentang Wakaf. Jakarta: t.p. 2006.

Direktorat Pemberdayaan Wakaf-Dirjen Bimbingan Masyarakat Islam. Strategi Pengembangan Wakaf Tunai di Indonesia. Jakarta: t.p. 2006.

Djunaidi, Ahmad dan Thobieb al-Asyhar. Menuju Era Wakaf Produktif. Jakarta: Mitra Abadi Press, 2006.

Halim, Abdul. Hukum Perwakafan di Indonesia. Ciputat: Ciputat Press, 2005.

Haq, Faishal. Hukum Wakaf dan Perwakafan di Indonesia. Pasuruan: PT. Garoeda Buana Indah, 1993.

Hasan, Sudirman. Wakaf Uang Perspektif Fiqih, Hukum Positif dan Manajemen. Malang: UIN-Maliki Press, 2011.

Ibn Qasim, Abu 'Abdillah Muhammad al-Syafi'iy. Fath\}al-Qari內. Surabaya: al-Hidayah, 1987.

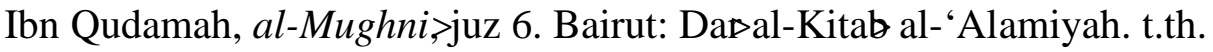

Ibn Saurah, Abu 'Isa Muhammad ibn 'Isa. Sunan al-Turmuæhi>Bairut: Daæal-Fikr, 2001.

Mannan, M. A. Sertifikat Wakaf Tunai. Jakarta: Ciber-PKTTI-UI, 2001.

Mardani. Aspek Hukum Lembaga Keuangan Syariah di Indonesia. Jakarta: Kencana, 2015. . Hukum Ekonomi Syariah di Indonesia. Bandung: PT Refika Aditama, 2011.

Mughniyah, Muhammad Jawad. Fiqih Lima Madzhab. Jakarta: Basrie Press, 1994. 
Munawwir, Ahmad Warson. Kamus Arab Indonesia Munawwir. Surabaya: Pustaka Progresif, 1997.

Muslim. Słh hol-Muslim, juz 2. Jakarta: Daæal-Ihya >al-Kutub al-'Arabiyah, t.th.

Praja, Juhaya S. Perwakafan di Indonesia. Bandung: Yayasan Piara, 1995.

Qahaf, Munzir. al-Waqf al-Islaæiiy Tatłwwuruhu>Idaฉatuhu, Tanmiyatuhu>terj. Muhyidin Mas Ridha. Jakarta: Khalifa, 2000.

Rozalinda. Ekonomi Islam Teori dan Aplikasinya pada Aktivitas Ekonomi. Jakarta: Rajawali Press, 2014.

Sari, Elsi Kartika. Pengantar Hukum Zakat dan Wakaf. Jakarta: PT. Grasindo, 2007.

Soemitra, Andri. Bank dan Lembaga Keuangan Syariah. Jakarta: Kencana, 2016.

http://www.sabilulhuda.org/index.php?option=com_content\&view=article\&id=64:manajemen -efektif-dana-wakaf-produktif\&catid=42: mutiara-hikmah\&Itemid=73. 